Interdisciplinary Contexts of Special Pedagogy
NUMBER 30/2020

\title{
Communicative competence of a child with cerebral palsy and mild intellectual disability
}

\begin{abstract}
Dominika Wiecha, Ewelina Zając, Communicative competence of a child with cerebral palsy and mild intellectual disability. Interdisciplinary Contexts of Special Pedagogy, no. 30, Poznań 2020. Pp. 243-258. Adam Mickiewicz University Press. ISSN 2300-391X. e-ISSN 2658-283X. DOI: https:// doi.org/10.14746/ikps.2020.30.12

In the article, the communicative competence of a 12 year old girl with cerebral palsy and mild intellectual disability was characterised. These developmental disorders exert a significant impact on child's skills in the field of speech expression and perception. Moreover, they lead to speech disorders: oligophasia and dysarthria. The case study method was used to conduct the research. In the first part of this article the authors described two issues: cerebral palsy and intellectual disability. They indicated the causes, as well as the most common symptoms of these developmental disorders. In the next part the authors provided an extensive description of various diagnostic tests. They enabled the researchers to explore, among others, speech expression and perception, as well as phonematic hearing. The results of these different tests were thoroughly analysed. Consequently, it has been proved that the level of child's linguistic and communication skills corresponds to the results achieved by children with similar deficits and disorders.
\end{abstract}

KEY WORDS: speech, communicative competence, cerebral palsy, intellectual disability, oligophasia, dysarthria 


\section{Introduction}

Cerebral palsy is "a group of permanent disorders of development, movement and posture, limiting motor activity, which are attributed to non-progressive disorders of the brain development of a foetus or a neonate" ${ }^{1}$ Movement disorders are often accompanied by sensory, cognitive, communication, perception, behavioural or seizure disorders. The majority of people with $\mathrm{CP}$ experience speech disorders $(50-85 \%)$, the most common of which are dysarthria, oligophasia, alalia, speech development delay due to hearing loss or deafness, dysglossia, muteness and stuttering. ${ }^{2}$ The main cause of speech development disorders accompanying the described neurological syndrome is damage to the central nervous system, which results in not only motor dysfunctions, but also sensory disorders, which is associated with a cognitive developmental delay in a child. Numerous researchers also indicate the important role of social factors, such as environmental neglect, limited social contacts and insufficient sensory stimulation, which inhibit or prevent the development of linguistic skills. ${ }^{3}$

According to the DSM-V classification, intellectual disability includes "disorders that begin in childhood and are characterised by intellectual difficulties as well as adaptation difficulties in conceptual, social, and practical areas of living. The following three criteria must be met: the presence of deficits in intellectual functioning, the presence of deficits in adaptation, resulting in failures in the achievement of developmental and socio-cultural standards (which makes it impossible to maintain independence and responsibility), the beginning of intellectual and adaptive deficits in the developmental period" 4 .

${ }^{1}$ M. Michalik, Mózgowe porażenie dziecięce w teorii i praktyce logopedycznej, Harmonia Universalis, Gdańsk 2015, p. 19.

2 U. Mirecka, Dyzartria w mózgowym porażeniu dziecięcym, Wydawnictwo Uniwersytetu Marii Curie-Skłodowskiej, Lublin 2013, p. 19.

${ }^{3}$ U. Mirecka, Dyzartria w mózgowym porażeniu dziecięcym, Wydawnictwo Uniwersytetu Marii Curie-Skłodowskiej, Lublin 2013, p. 22.

${ }^{4}$ P. Gałecki, M. Pilecki i in., Kryteria diagnostyczne zaburzeń psychicznych DSM-5, Edra Urban \& Partner, Wrocław 2018, p. 37-38. 


\section{Research methodology}

The conducted study included a 12-year-old girl diagnosed with mild intellectual disability and severe cerebral palsy in the form of spastic paresis of both lower limbs. She is brought up in a reconstructed family, the constant care is provided by her mother, but her stepfather is involved in her upbringing. The girl is an only child. The delivery did not take place on time, but the child was born naturally. The condition of the neonate was not normal - the girl weighed 1400 grams and received 7 points on the Apgar scale. According to the mother, the course of the adaptation and neonatal periods was normal. There were no cases of any diseases or disability in the family of the child.

In order to conduct an in-depth and reliable diagnosis of the language difficulties of the respondent, various tests and examinations were used to check individual linguistic skills. The following tests were used in the research process: Comprehensive speech therapy examination with pictorial material ${ }^{5}$, Dysarthria scale: version for children ${ }^{6}$, Speech therapy screening test for school-age children ${ }^{7}$, Child Speech Therapy Assessment Sheets - CSTAS ${ }^{8}$, Child Vocabulary Test ${ }^{9}$, Linguistic Skills Test ${ }^{10}$, a test to investigate the knowledge of phrasemes (own elaboration), a pictorial questionnaire for articulation testing (own elaboration).

${ }^{5}$ D. Emiluta-Rozya, Całościowe badanie logopedyczne z materiałem obrazkowym, Wydawnictwo Akademii Pedagogiki Specjalnej, Warsaw 2013.

${ }^{6}$ K. Gustaw, U. Mirecka, Skala dyzartrii: wersja dla dzieci, Wydawnictwo Continuo, Wrocław 2000.

7 S. Grabias, Z.M. Kurkowski, T. Woźniak, Logopedyczny test przesiewowy dla dzieci w wieku szkolnym, Maria Curie-Skłodowska University. Department of Logopaedics and Applied Linguistics, Lublin 2002.

${ }^{8}$ J. Gruba, Karty Oceny Logopedycznej Dziecka - KOLD, KOMLOGO, Gliwice 2016.

9 Z. Tarkowski, Test Słownika Dziecka, Wydawnictwo Digi-Cad-Projekt, Lublin 1996.

10 Z. Tarkowski, Test Sprawności Językowej, Wydawnictwo Digi-Cad-Projekt, Lublin 2001. 


\section{Speech therapy diagnosis}

The speech therapy diagnosis consisted of examining the following skills:

1. articulation apparatus performance test,

2. articulation test,

3. phonematic hearing test,

4. phonation test,

5. prosody test,

6. speech understanding test,

7. test of active speech - narrative speech,

8. test of active speech - dialogue-related speech,

9. test of active speech - monologue-related speech,

10. test of active speech - creating requests, orders, wishes and invitations,

11. vocabulary resource test,

12. inflection test,

13. self-esteem test.

\section{Articulation apparatus performance test}

The respondent had a problem with repeating the exercises checking the functioning of the articulator muscles. She had the greatest difficulties with: pushing her left/right cheek with her tongue, quickly contracting and stretching her lips, pointing her tongue to the right/left corner of her lips and quickly repeating [u]-[i], [a]-[y] and [pa]-[ta]-[ka]. Attempts to retract the tongue into the mouth and lift the tip of the tongue inside/outside the mouth were assessed slightly better. A significant slowdown in the movements of the mandible has been noticed. Swallowing of saliva at rest was characterised by slight abnormalities, consisting in the insertion of the tongue between the teeth by the respondent (infantile swallowing). While speaking, the degree of the present disorders in- 
creased, and sometimes some saliva leaked out. During the observation, no involuntary movements of the girl were recorded. No asymmetry in the face was observed, both at rest and while speaking.

\section{Articulation test}

The speech of the respondent is quite well understood, not only for people from her immediate surroundings, but also for those who do not spend time with her on a daily basis. In the speech of the respondent there are articulation disorders, which is caused by the minimal work of the articulation organs (due to disorders of their muscle tone resulting from cerebral palsy) and the related lack of tongue erection. Incorrect articulation of the phones of the rustling

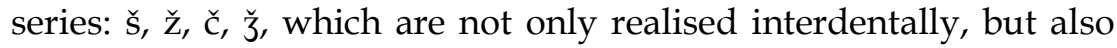
replaced by hissing phones: s, z, c, 3, was diagnosed. Interdental pronunciation also applies to the remaining anterolinguistic dental phones: $t, d, n$ and the anterolinguistic gingival phone 1 . The low mobility of the tongue also results in the lack of vibration of its tip during articulation of the $r$ phone, which makes the sound of this phone significantly different from the standard. Other phones, or backlingual, middle lingual, labiodental, bilabial phones and all vowels are correctly realised. In the speech of the child numerous pathological linguistic phenomena, such as: substitutions (e.g. Capka-czapka [hat]), elisions (e.g. xopak-chłopak [boy]) or simplification of consonant groups (e.g. pčoua-pszczoła [bee]) can be observed.

\section{Phonematic hearing test}

During the test ${ }^{11}$ the girl correctly distinguished all phone oppositions. Occasional errors, consisting in indicating the wrong pic-

11 Based on D. Emiluta-Rozya, Całościowe badanie logopedyczne z materiałem obrazkowym, Wydawnictwo Akademii Pedagogiki Specjalnej, Warsaw 2013. 
ture, probably resulted from fatigue with the test formula. The results of phonematic hearing measurements obtained on the basis of the task from the Speech therapy screening test for school-age children ${ }^{12}$ are in contrast to the results obtained in the previous tasks. Probably, the respondent had a problem with understanding the formula of the proposed exercise, the perception of false words, and thus qualifying them as identically or differently sounding (after repeating the words, she sometimes changed her answer). Therefore, the results of the first test should be considered reliable, which means that the child does not have phonematic hearing disorders.

\section{Phonation test}

This part of the diagnosis began with the assessment of voice projection, asking for the emission of a phone [a]. The respondent presented a soft voice projection. However, the phonation time was significantly shortened, the girl had been unable to pronounce the vowel fluently even for a few seconds (such a result may also have been caused by the limited ability to understand the commands addressed to her). Both in terms of the intensity and pitch of the voice of the respondents, significant abnormalities can be observed, i.e. the lack of stability of these parameters during the speech. Additionally, the girl was unable to gradually increase or decrease the pitch of her voice, which proves her very limited phonation abilities.

\section{Prosody test}

Various aspects of the suprasegmental plane of speech were assessed, including: intonation, accent, rhythm and pace of speech. The respondent is able to properly imitate the intonation, which she

12 S. Grabias, Z.M. Kurkowski, T. Woźniak, Logopedyczny test przesiewowy dla dzieci w wieku szkolnym, Maria Curie-Skłodowska University. Department of Logopaedics and Applied Linguistics, Lublin 2002. 
presented by a correct repetition of a declarative, imperative and interrogative sentence. In her own statements, she also keeps the correct intonation line, possible abnormalities occur only in situations of high excitement. However, the girl has great difficulties in using the correct accent. The ability to repeat sentences with the use of an appropriate logical accent is severely impaired, the respondent did not seem to hear the difference in the sentences spoken by the examiner and repeated them incorrectly. On the other hand, deviations from the norm in the scope of maintaining the correct rhythm in sentences can be considered moderately severe, and they are manifested by a slight tendency to scansion. The girl is able to maintain an appropriate pace of speech, both when repeating sentences and when speaking freely. She also uses phrases of the correct length.

\section{Speech understanding test}

The study covered understanding of single words, longer statements and phrasemes, as well as understanding of commands.

Single-word comprehension test was performed on the basis of a sample from Child Speech Therapy Assessment Sheets ${ }^{13}$ from the subtest intended for children aged 8-9 years. It consisted in reading three words by the examiner, providing a definition of one of them, and then indicating a word matching the description by the responder. The task assessed knowledge of nouns, verbs, adjectives and adverbs. The respondent obtained a good result by correctly specifying all parts of speech except for two nouns. This relatively high level of task performance is probably related to the fact that the girl did not have to remember the desired name, but chose the correct answer out of the three previously provided words. This formula of the exercise excluded possible problems with retrieving

${ }^{13}$ J. Gruba, Karty Oceny Logopedycznej Dziecka - KOLD, KOMLOGO, Gliwice 2016. 
names on her own and allowed the girl to present real comprehension skills, which remain at a high level.

To test the comprehension of a longer statement, the subtest on fairy tale comprehension from the Linguistic Skills Test was used.14 The task of the respondent was to answer questions about the fairy tale after it was read twice by the examiner. The girl answered only single questions, several times mechanically quoted the text of the fairy tale, without using the remembered information in a creative way to provide the correct answer. The difficulties of the respondent with the correct performance of the task may be related to the rather complicated structure of the text (dependent clauses and coordinate clauses) and the presence of a large number of protagonists (a donkey, a dog, a master, a wolf).

In order to test the ability to understand phrasemes, the authors used their own diagnostic test, on the basis of which it was found that the knowledge of phrasemes (in the form of expressions, terms and phrases) remains at a very low level. The girl can only explain single phrases that are often used in everyday life (e.g. wilczy głód [ravenous appetite], złota rączka [handyman]). She tried to present the other set phrases in a literal way, and was unable to reach their figurative, metaphorical meaning. The respondent several times only paraphrased the content of the phraseme, without attempting to present its hidden meaning.

Understanding of instructions was also tested on the basis of a sample taken from the CSTAS. 15 The respondent was given two commands: the first one was performed correctly after a hint, and the second was performed without errors. Correct performance of the above tests confirms the conclusions drawn during the observation - the respondent has no difficulties understanding the messages addressed to her, follows the instructions of educators and other people and tries (if possible) to do what she is asked to do.

14 Z. Tarkowski, Test Sprawności Językowej, Wydawnictwo Digi-Cad-Projekt, Lublin 2001.

15 J. Gruba, Karty Oceny Logopedycznej Dziecka - KOLD, KOMLOGO, Gliwice 2016. 


\section{Test of active speech - narrative speech}

Narrative speech was tested on the basis of a picture story from the Speech therapy screening test for school-age children.16 The task showed large deficits of the respondent in the field of cause-andeffect thinking and understanding time relations. The girl was not able to connect the pictures on her own, had a problem with applying the appropriate narrative line and correctly describing the situation. The respondent used short, interrupted sentences, used numerous pauses, did not refer to the emotions felt by the protagonists of the story, did not add an author's commentary. However, there were visible attempts to create an appropriate narrative structure, for example the formula of "one day". After some hints provided by the examiner, the girl correctly presented the consecutive events, maintaining semantic coherence. Nevertheless, the ability to create a narrative statement based on a picture story should be assessed as significantly disturbed.

\section{Test of active speech - dialogue-related speech}

The test was aimed at assessing the ability to produce a statement of a dialogue nature. The respondent kept the correct pattern of this form of expression, or she used polite phrases at the beginning and end of the conversation, after asking a question, she waited for the interlocutor's answer and reacted to the content they provided. The statement was syntactically consistent, there were no pauses or repetitions. However, logical errors and difficulties in understanding time relations can be noticed.

${ }^{16}$ S. Grabias, Z.M. Kurkowski, T. Woźniak, Logopedyczny test przesiewowy dla dzieci w wieku szkolnym, Maria Curie-Skłodowska University. Department of Logopaedics and Applied Linguistics, Lublin 2002. 


\section{Test of active speech - monologue-related speech}

The monologue-related speech was assessed based on the Linguistic Skills Test ${ }^{17}$ and spontaneous statements. The syntactic structure of the text created by the respondent is characterised by a huge diversification. It includes both compound-complex and simple sentences with occasional inflectional errors. The created text, although semantically coherent, contained pauses and repetitions which indicate difficulties in recreating the content of the story.

During spontaneous speeches, the girl often talked about her experience related to school, contacts with peers and family life. The statements were dominated by the expressive function, the respondent signalled her emotions both verbally (using exclamations and emotional expressions) and non-verbally - through laughter or crying. The monologues of the respondent contained numerous pauses and repetitions, which may indicate difficulties in formulating thoughts and experience. The statements often lacked a logical order, and the presented information did not follow the sequence of cause and effect. The occurring logical errors (e.g. lack of reference to time relations) definitely hampered the reception of statements, making them sometimes completely incomprehensible. However, the girl used a wide range of vocabulary, as well as extensive syntactic structures, such as dependent clauses and coordinate clauses.

\section{Test of active speech - creating requests, orders, wishes and invitations}

The level of mastery of the pragmatic skill in creating requests and orders remains at a very high level. The girl answered all the questions correctly, demonstrating that she can skilfully communicate her thoughts and needs.

17 Z. Tarkowski, Test Sprawności Językowej, Wydawnictwo Digi-Cad-Projekt, Lublin 2001. 
The wishes created by the respondent contained all important elements, such as the addressee, the occasion of the wishes and their content. This form of expression was probably practised many times during school classes, thanks to which the girl did not experience any problem with its creation. The respondent had problems with the arrangement of the content of the invitation. The respondent included in it all the desired elements only after being asked auxiliary questions. Nevertheless, the level of pragmatic performance remains at a level adequate to the level of the intellectual development of the child.Vocabulary range test

In order to examine the vocabulary resource, the subtest Vocabulary from the Linguistic Skills Test ${ }^{18}$, which consisted in guessing the answers to ten riddles read by the examiner, was used The respondent provided only three names (a lion, a forest, a fireman), and she guessed two words after the hint. This proves the limitations in abstract thinking and difficulties in retrieving names, because the girl knows and uses on her own words being answers to the riddles. Therefore, the results of the test are in contradiction with the vocabulary resources presented by the respondent on a daily basis in spontaneous statements. It also indicates the need for continuous repetition of already acquired vocabulary, and using it in various games, exercises and everyday situations.

The task of the respondent was also to name as many words as possible that fit the described category (e.g. toys, vehicles). Despite providing an example, the girl did not seem to understand the command because after a few words she ended up saying "That's it". As in previous tests, she did not present the richness of her active vocabulary and thus showed difficulties in the formation of secondary words.

Another test, taken from the Child Vocabulary Test ${ }^{19}$, the assessment of the ability to form primary words. It is at a fairly high level,

18 Z. Tarkowski, Test Sprawności Językowej, Wydawnictwo Digi-Cad-Projekt, Lublin 2001.

${ }^{19}$ Z. Tarkowski, Test Stownika Dziecka, Wydawnictwo Digi-Cad-Projekt, Lublin 1996. 
although the respondent had difficulty in creating superior descriptors to verb names. The results of the described test show decent skills in categorising individual items and assigning words to specific lexical and semantic fields. The aim of the next test was to test the ability to define individual items or concepts. The full definition of a word should include the class, function and trait of the item or be synonymous with the word. The respondent provided a fully correct answer only three times (breakfast, kitchen, dwarf). Usually, her statements contained a description of one of the traits of the item or its function, but they lacked specific information allowing for a clear definition of the item in question. When creating definitions, the respondent referred to her experience, the closest environment or supported herself with a gesture. This proves that she has significant difficulties in generalising and distinguishing essential traits of a given item or phenomenon, which is characteristic of children with this type of intellectual disability.

\section{Inflection test}

The results achieved by the girl indicate high declension skills. The respondent answered all the questions with almost no mistakes, thus demonstrating a high level of the tested linguistic ability.

\section{Self-esteem test}

The aim of the task was to check the individual attitude of the respondent to the her dysarthria disorders. The questions concerned four aspects: the assessment of the intelligibility of her own statements, fatigue while speaking, difficulties with breathing and vocal difficulties. Due to the reduced intellectual capacity, the respondent had problems understanding the questions. She mentioned that what she says to her mother, teachers and colleagues is not always understandable. She stated that she did not get tired while speak- 
ing, although during the observation muscle fatigue or a problem with respiratory-phonation coordination could be noticed. She added that she had no problems with breathing, and stated "My speech is sometimes not straight, I lose my speech, something like that." This may mean that the respondent is aware of her speech disorders, comparing herself to other people, she notices a different way of expressing, but she is unable to precisely describe the experienced difficulties.

\section{Conclusion}

The results of the conducted exercises and diagnostic tests correspond to the information contained in the literature on the linguistic and communicative competence of people with mild intellectual disability and $\mathrm{CP}$.

The development of the linguistic skills of the respondent remains at the level adequate to her intellectual and executive abilities. The girl has a large resource of vocabulary, but has problems with using it in task situations and retrieving previously learned names. Difficulties arise in creating definitions and secondary words. The respondent showed the correct level of understanding individual words (from the field of different parts of speech) and commands, but she had a significant problem with understanding longer, more complex texts and phrasemes. The girl has mastered the declension skill to a high level, but it is difficult for her to notice grammatical or semantic errors in the statements of other people.

The degree of realisation of various types of statements (monologues, dialogues and narratives), and thus the level of the development of interactive skills, is reduced as a result of deficits in cause-effect thinking and difficulties in retrieving names. Although the statements created by the respondent are often chaotic and incoherent, she is able to transfer her thoughts, needs or the most important content in an understandable way.

The respondent showed a high level of mastering communication competence. This means that despite the linguistic and cogni- 
tive deficits, she is able to create statements adequate to the communicative situation, the rank of the recipient and the place of the conversation.

The level of understanding single words as well as sentences and free speech is good. Despite the significant degree of speech impediments, statements of the respondent are almost fully understood even by people from outside her environment. Possible difficulties with the reception of individual words do not have a negative impact on the overall understanding of what the girl wants to say to her interlocutor.

During the examination, no hypernasal or hyponasal speech was noticed, neither during the expression of single words, and sentences by the girl, nor during free speech. However, there were numerous abnormalities related to prosody, phonation and performing alternating movements. However, the disorders occurring in these spheres, do not affect the level of understanding of the utterance, and therefore the need of their elimination is smaller than in the case of deficits in other linguistic skills.

The respondent rarely commits grammatical or semantic errors, but she has trouble finding them on her own. She can notice the absurdity resulting from her errors and, after asking an auxiliary question by the examiner, she provides a correct answer. This may be related to deficits in the cognitive sphere. It also reflects the difficulties of the respondent in acquiring the grammatical rules of the Polish language, especially the inflection of words. Problems with understanding time relations are also visible.

To sum up, a serious neurological disorder, which is cerebral palsy, as well as a mild co-occurring intellectual disability, undoubtedly influences the degree of mastery of linguistic and communication skills by the respondent.According to U. Mirecka, "the level of language mastery and the ability to use it in social situations are quite varied in children with cerebral palsy". ${ }^{20}$ In addition, peo-

20 U. Mirecka, Dyzartria w mózgowym porażeniu dziecięcym, Wydawnictwo Uniwersytetu Marii Curie-Skłodowskiej, Lublin 2013, p. 19. 
ple with intellectual disability experience a whole spectrum of disorders in the development of communication, speech and language from the inability to communicate, through the use of alternative and assisted communication, to speech development delays or articulation abnormalities. ${ }^{21}$ The language and communication difficulties occurring in the respondent are the result of not only her reduced intellectual level, and therefore deficits in the cognitive and social sphere, but also result from disorders of the CP type. It is not without reason that in recent years the postulate that the dysarthria resulting from $\mathrm{CP}$ should be treated to a large extent as a separate, autonomous unit has gained popularity. ${ }^{22}$ This is because the discussed speech disorder has slightly different conditions in this neurological syndrome, which is associated with an extended spectrum of symptoms - "motor, sensory, intellectual and social macro- and microdeficits prevent the child from mastering their linguistic competence on their own". ${ }^{23}$ This leads to a broader look at the described speech disorder and a different approach to its specificity.

Undoubtedly, the presence of such complex disorders in the tested child has a comprehensive impact on her development, including language development. However, systematic and multispecialist therapeutic interactions have a positive effect on the process of shaping and developing the necessary skills, which has been demonstrated in the present paper.

\section{References}

Błeszyński J.J., Niepełnosprawność intelektualna. Mowa - język - komunikacja, Harmonia Universalis, Gdańsk 2013.

${ }^{21}$ J.J. Błeszyński, Niepetnosprawność intelektualna. Mowa - język - komunikacja, Harmonia Universalis, Gdańsk 2013, p. 40.

${ }_{22}$ M. Michalik, Mózgowe porażenie dziecięce w teorii i praktyce logopedycznej, Harmonia Universalis, Gdańsk 2015, p. 69.

${ }^{23}$ M. Michalik, Mózgowe porażenie dziecięce w teorii i praktyce logopedycznej, Harmonia Universalis, Gdańsk 2015, pp. 71-77. 
Emiluta-Rozya D., Całościowe badanie logopedyczne z materiałem obrazkowym, Wydawnictwo Akademii Pedagogiki Specjalnej, Warsaw 2013.

Gałecki P., Pilecki M. i inni, Kryteria diagnostyczne zaburzeń psychicznych DSM-5, Edra Urban \& Partner, Wrocław 2018.

Grabias S., Kurkowski Z. M., Woźniak T., Logopedyczny test przesiewowy dla dzieci w wieku szkolnym, Maria Curie-Skłodowska University. Department of Logopaedics and Applied Linguistics, Lublin 2002.

Gruba J., Karty Oceny Logopedycznej Dziecka - KOLD, KOMLOGO, Gliwice 2016.

Gustaw K., Mirecka U, Skala dyzartrii: wersja dla dzieci, Wydawnictwo Continuo, Wrocław 2000.

Michalik M., Mózgowe porażenie dziecięce w teorii i praktyce logopedycznej, Harmonia Universalis, Gdańsk 2015.

Mirecka U., Dyzartria w mózgowym porażeniu dziecięcym, Wydawnictwo Uniwersytetu Marii Curie-Skłodowskiej, Lublin 2013.

Tarkowski Z, Test Sprawności Językowej, Wydawnictwo Digi-Cad-Projekt, Lublin 2001.

Tarkowski Z., Test Słownika Dziecka, Wydawnictwo Digi-Cad-Projekt, Lublin 1996. 